\title{
Saturation kinetics of magnesium efflux across the rumen wall in heifers
}

\author{
BY H. MARTENS \\ Department of Physiology, School of Veterinary Medicine, Bischofsholer Damm 15, \\ D-3000 Hannover 1, West Germany
}

(Received 26 August 1982 - Accepted 6 September 1982)

\begin{abstract}
1. Absorption of magnesium from the temporarily-isolated, emptied and washed rumen of four 10-12-month-old heifers was measured at five different $\mathrm{Mg}$ concentrations $(2 \cdot 5,5 \cdot 0,7 \cdot 5,12 \cdot 5$ and $20 \mathrm{mmol} / \mathrm{l})$.

2. Net absorption of $\mathrm{Mg}$ was observed at all concentrations. Saturation occurred at a concentration of $12.5 \mathrm{mmol} \mathrm{Mg} / 1$.

3. Using an Eadie-Hofstee plot, the Michaelis-Menten constant $\left(K_{m} ; 11.43 \mathrm{mmol} / \mathrm{l}\right)$ and maximal efflux $\left(V_{\text {max }} ; 120 \cdot 3 \mu \mathrm{mol} / \mathrm{min}\right)$ were estimated.

4. The phenomenon of saturation supports the assumption that $\mathrm{Mg}$ transport across the rumen wall of heifers is an active process.
\end{abstract}

In sheep and also in cows net absorption of magnesium from gastrointestinal contents occurs mainly before these reach the duodenum, i.e. at the forestomach-stomach level (Rogers \& van't Klooster, 1969; Pfeffer et al. 1970; Horn \& Smith, 1978). In sheep the reticulo-rumen has been identified as the main site of absorption by both in vivo (Tomas \& Potter, 1976) and in vitro experiments (Martens, 1978), absorption being by active, sodium-linked transport (Martens, 1978). In contrast, working with young steers, Horn \& Smith (1978) found that only negligible amounts of $\mathrm{Mg}$ were absorbed from the reticulo-rumen. They concluded from their studies that the main site of pre-intestinal $\mathrm{Mg}$ absorption was the omasum. This conclusion has been confirmed experimentally by studies carried out in young steers by Edrise \& Smith (1979).

The present study was conducted to clarify further the contradictory results in cattle as compared with sheep, and to obtain information on the mechanism of $\mathrm{Mg}$ absorption from the rumen in heifers.

\section{EXPERIMENTA L}

Animals and feeding

Four heifers, 10-12 months old and weighing 170-240 kg, were used. Each animal was fitted with a large fistula (diameter $120-140 \mathrm{~mm}$ ) in the dorsal sac of the rumen. The fistulas were prepared 6 months before the experiments were started. Between the experiments, the fistulas were kept closed with rubber plugs fixed between two plastic discs inside and outside the rumen respectively.

The animals were fed twice daily (08.00 and 16.00 hours) with $600 \mathrm{~g}$ commercial concentrate mixture $(170 \mathrm{~g}$ crude protein (nitrogen $\times 6 \cdot 25) / \mathrm{kg}$ and hay. The animals had free access to water and salt blocks.

\section{Preparation of the rumen and saliva bypass}

The animals were restrained in a stanchion before the morning feed, and the rumen was emptied through the fistula. Rumen contents were kept in a water-bath at $39^{\circ}$ and returned to the rumen at the end of the experiment. Then the rumen was washed with buffer solution (Table 1) until the cleansing fluid was clear (six to eight washings with 2-31 buffer each).

A saliva collector (Von Engelhardt \& Sallmann, 1970) was introduced, through the rumen 
Table 1. Compositions (mmol/l) of the buffers used in the temporarily-isolated, washed reticulo-rumen

\begin{tabular}{|c|c|c|c|c|c|c|}
\hline Compound & $\begin{array}{l}\text { Rinsing } \\
\text { buffer*广 }\end{array}$ & \multicolumn{5}{|c|}{ Experimental buffer* $\dagger$} \\
\hline $\mathrm{NaCl}$ & 50 & 50 & 48 & 46 & $39 \cdot 5$ & 34 \\
\hline $\mathrm{NaHCO}_{3}$ & 45 & 45 & 45 & 45 & 45 & 45 \\
\hline $\mathrm{Na}_{2} \mathrm{HPO}_{4}$ & 2 & 2 & 2 & 2 & 2 & 2 \\
\hline $\mathrm{KC}\rfloor$ & 5 & 5 & $4 \cdot 5$ & 4 & 3 & 1.5 \\
\hline $\mathrm{KHCO}_{3}$ & 20 & 20 & 20 & 20 & 20 & 20 \\
\hline Sodium acetate & 25 & 25 & 25 & 25 & 25 & 25 \\
\hline Propionic acid & 10 & 10 & 10 & 10 & 10 & 10 \\
\hline Butyric acid & 5 & 5 & 5 & 5 & 5 & 5 \\
\hline $\mathrm{MgCl}_{2 \neq} \ddagger$ & $2 \cdot 5$ & $2 \cdot 5$ & 5 & $7 \cdot 5$ & $12 \cdot 5$ & 20 \\
\hline $\mathrm{CaCl}_{2}$ & 2 & 2 & 2 & 2 & 2 & 2 \\
\hline Glucose & 5 & 5 & 5 & 5 & 5 & 5 \\
\hline
\end{tabular}

${ }^{*} \mathrm{pH}$, after equilibration with carbon dioxide at $39^{\circ}$ was $6 \cdot 6 \cdot 6 \cdot 8$.

$\dagger$ Osmolarity was approximately $300 \mathrm{mosmol} / \mathrm{l}$.

¥ The concentration of magnesium was increased from $2.5 \mathrm{mmol} / 1$ to $20 \mathrm{mmol} / \mathrm{l}$ at the expense of sodium and potassium.

fistula, and fixed in the lower part of the oesophagus to prevent saliva from entering the rumen during the period of experimentation. Salivary secretion under these conditions was between 2 and $31 / \mathrm{h}$. The saliva collected from the oesophagus was continuously returned to the animal through a tube passing through the rumen fistula and through the omasum into the abomasum.

\section{Absorption experiments}

Immediately before an experiment started, the emptied rumen was washed with buffer once more since traces of saliva might have passed into it during manipulation with the saliva collector. Then the rumen wall was adapted to the experimental conditions by introducing, for a period of $10 \mathrm{~min}, 21$ of the buffer solution to be used in the following experiment. The absorption studies were carried out using buffer solutions with different $\mathrm{Mg}$ concentrations $(2 \cdot 5,5 \cdot 0,7 \cdot 5,12.5$ and $20 \mathrm{mmol} / 1)$ and containing $1.92 \mathrm{mmol}$ chromium (in the form of Cr-EDTA)/l as a volume marker (prepared according to Binnerts et al. 1968). The compositions of the buffer solutions are shown in Table 1.

A volume of 31 of the appropriate buffer solution was adjusted to body temperature, gassed with carbon dioxide, and introduced into the emptied and washed rumen. Samples of $10 \mathrm{ml}$ were taken at zero time and after 5,20,40 and $60 \mathrm{~min}$, then the remaining fluid was removed from the rumen. During the $1 \mathrm{~h}$ period the fluid in the rumen was continuously gassed with $\mathrm{CO}_{2}$ and thus stirred. The samples were stored at $4^{\circ}$ for subsequent analysis.

Three such experiments with different buffer solutions were performed in one animal/d. After the last experiment the previously removed rumen contents were returned to the rumen.

Disorders of rumen functions were not observed and no animal was used more than once weekly.

\section{Calculation of $\mathrm{Mg}$ absorption}

Net absorption of $\mathrm{Mg}$ during a given period of time was calculated by the following equation:

$$
A=\frac{\left(V_{B} C_{B}\right)-\left(V_{E} C_{E}\right)}{t},
$$


where $A$ is the net absorption ( $\mu \mathrm{mol} / \mathrm{min}), t$ is the experimental period ( $\mathrm{min}), V$ is the volume of fluid in the rumen (l), $C$ is the $\mathrm{Mg}$ concentration (mmol/l), and $B, E$ are the beginning and end of the experimental period respectively.

\section{Analytical procedures}

The samples were diluted with deionized water to give solutions ${ }^{-}$with concentrations $(\mu \mathrm{mol} / \mathrm{l})$ of approximately $4 \cdot 0-16 \mathrm{Mg}$ and $19-77 \mathrm{Cr}$.

$\mathrm{Mg}$ and $\mathrm{Cr}$ were estimated by atomic absorption spectrophotometry (Perkin-Elmer AAS 400), according to the manufacturer's instructions, using an air-acetylene flame. Osmolarity was determined by a freezing-point-depression osmometer (Knauer). $\mathrm{pH}$ was measured immediately after the sample was taken.

\section{Statistical treatment}

Values are expressed as means and standard deviations. The regressions were calculated by the least-squares method.

\section{RESULTS}

Net absorption from the rumen increased with increasing concentration of $\mathrm{Mg}$ in the buffer solution. An approximately linear relationship between $\mathrm{Mg}$ absorption and $\mathrm{Mg}$ concentration in the artificial rumen fluid was observed between 2.5 and $12.5 \mathrm{mmol} / 1$ (Fig. 1) but the efflux of $\mathrm{Mg}$ from the rumen increased much less when the $\mathrm{Mg}$ concentration was raised above 12.5 to $20 \mathrm{mmol} / \mathrm{l}$. Using the Eadie-Hofstee Plot, the Michaelis-Menten constant $\left(K_{m}\right)$ was calculated as $11.43 \mathrm{mmol} / \mathrm{l}$, and maximal efflux $\left(V_{\max }\right) 120.3 \mu \mathrm{mol} / \mathrm{min}$ (Fig. 2 ).

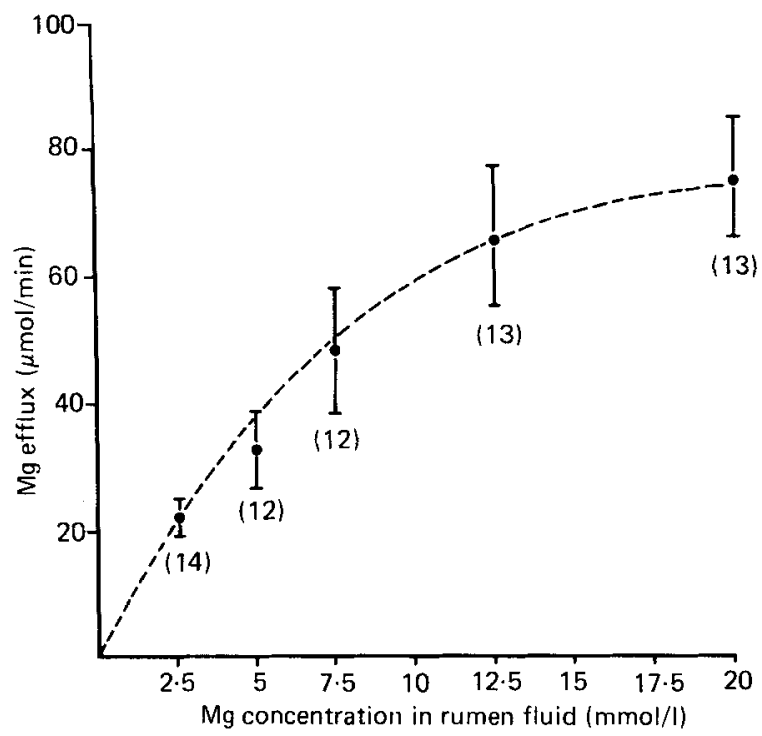

Fig. 1. Relationship between the magnesium concentration in the artificial rumen fluid (mmol/1) and the $\mathrm{Mg}$ efflux $(\mu \mathrm{mol} / \mathrm{min})$ was calculated from the first $20 \mathrm{~min}$ of the experiments. Points are means, and standard deviations are represented by vertical bars. The points were joined by hand. Values in parentheses are numbers of observations. 


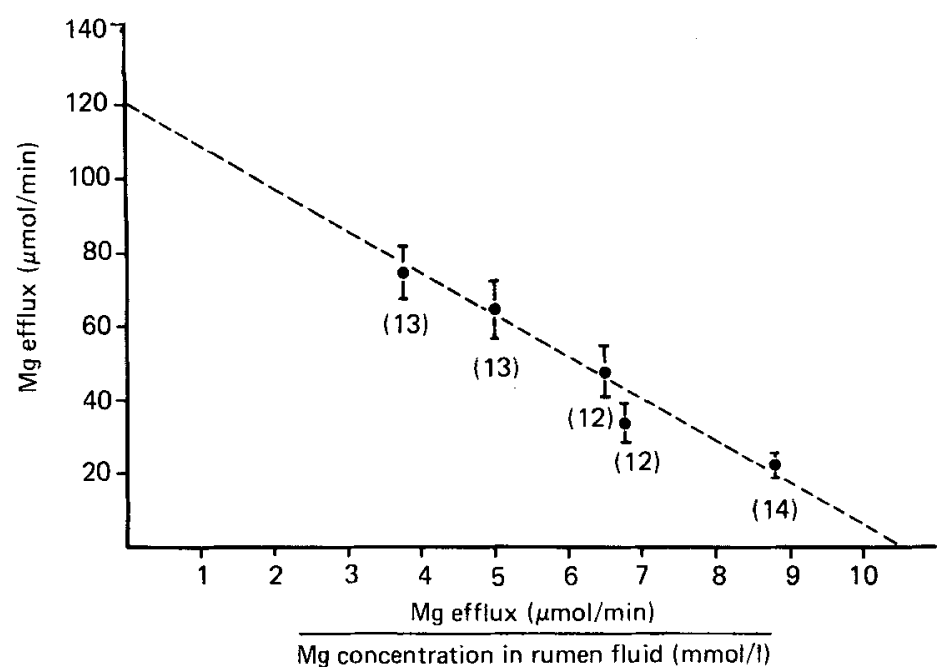

Fig. 2. Eadie-Hofstee plot from the values given in Fig. 1. The linear relationship is described by the equation: $y=120.3-11.43 \times(r 0.81 ; P<0.001)$. Points are means, and standard deviations are represented by vertical bars. Values in parentheses are numbers of observations.

\section{DISCUSSION}

The results shown in Fig. 1 demonstrate that the Mg transport across the rumen wall approached saturation at $\mathrm{Mg}$ concentrations of $12.5 \mathrm{mmol} / \mathrm{l}$. The saturation kinetics can be described by the equation

$$
\mathrm{Mg} \text { efflux }=V_{\text {max }}-K_{m} \frac{\mathrm{Mg} \text { efflux }}{[\mathrm{Mg}]} \text {, }
$$

where $[\mathrm{Mg}]$ is the $\mathrm{Mg}$ concentration $(\mathrm{mmol} / \mathrm{l})$ in the arterial rumen fluid.

The saturation kinetics obtained support the assumption that $\mathrm{Mg}$ interacts with a membrane component and passes across the rumen epithelium via a transcellular pathway. This would suggest a carrier-mediated mechanism to be involved in the transfer of $\mathrm{Mg}$ across the rumen wall. It is concluded that $\mathrm{Mg}$ is transported by an active process as described for sheep (Martens et al. 1978) though differing in that $\mathrm{Mg}$ absorption in sheep was saturated at an $\mathrm{Mg}$ concentration of approximately $4 \mathrm{mmol} / \mathrm{l}$ (Brown et al. 1978; Martens, 1979).

The results reported here appear to be in disagreement with the results of Horn \& Smith (1978) who observed absorption of only trace amounts of $\mathrm{Mg}$ from the rumen of young steers. These contradictory results might be explained on the basis of the different methods used. Horn \& Smith (1978) infused into the rumen a large amount of $\mathrm{Mg}(6 \mathrm{~g})$ and the ratio, magnesium: water-soluble marker (polyethylene glycol) in the rumen fluid was determined over a $10 \mathrm{~h}$ period. The high dose of $\mathrm{Mg}$ increased both the pool and the concentration of $\mathrm{Mg}$ in the rumen considerably, resulting in initial $\mathrm{Mg}$ concentrations in the rumen fluid of approximately $15 \mathrm{mmol} / 1$. According to the results from the present experiments, at such concentrations $\mathrm{Mg}$ transport should be saturated. It should also be noted that, for analytical reasons, measurement of absorption from the rumen becomes increasingly difficult at high intra-rumen concentrations and large pool sizes, as was the case in the experiments of Horn \& Smith (1978). Since in the present experiments the $\mathrm{Mg}$ pool was kept small, $\mathrm{Mg}$ absorption could be determined more precisely. As shown in Table 2 the quantities of $\mathrm{Mg}$ absorbed $/ \mathrm{h}$ were between 8 and $20 \%$ of the pool.

Absorption of $\mathrm{Mg}$ observed in the present studies appears to be unusually high, e.g. 
Table 2. Pool size and amount of magnesium absorbed from the rumen in heifers

\begin{tabular}{|c|c|c|c|}
\hline \multirow{2}{*}{$\begin{array}{c}\mathrm{Mg} \\
\text { concentration } \\
(\mathrm{mmol} / \mathrm{l})\end{array}$} & \multirow{2}{*}{$\begin{array}{c}\mathrm{Mg} \\
\text { pool } \\
(\mathrm{mmol})\end{array}$} & \multicolumn{2}{|c|}{$\begin{array}{c}\text { Amount of } \mathrm{Mg} \\
\text { absorbed }\end{array}$} \\
\hline & & $\mathrm{mmol} / \mathrm{h}$ & $\%$ of pool \\
\hline $2 \cdot 5$ & $7 \cdot 5$ & 1.47 & $19 \cdot 6$ \\
\hline $5 \cdot 0$ & $15 \cdot 0$ & $2 \cdot 27$ & $15 \cdot 1$ \\
\hline $7 \cdot 5$ & $22 \cdot 5$ & $3 \cdot 24$ & 14.4 \\
\hline $12 \cdot 5$ & $37 \cdot 5$ & 4.85 & $12 \cdot 9$ \\
\hline $20 \cdot 0$ & $60 \cdot 0$ & $4 \cdot 81$ & $8 \cdot 0$ \\
\hline
\end{tabular}

approximately $2 \cdot 2 \mathrm{mmol} \mathrm{Mg} / \mathrm{h}$ were absorbed from the ventral rumen sac at a concentration of $5 \mathrm{mmol} / \mathrm{l}$. A similarly high absorption was also found in sheep, using the same experimental approach (Martens, 1979). Several factors are likely to have contributed to this high $\mathrm{Mg}$ absorption: (i) there was a high $\mathrm{Na}: \mathrm{K}$ value (5) in the buffer solution, known to impreve $\mathrm{Mg}$ absorption; (ii) the buffer solution was continuously gassed with $\mathrm{CO}_{2}$ to maintain anaerobic conditions, and this may have increased blood flow through the rumen wall (Thorlacius, 1972) as well as $\mathrm{Mg}$ absorption (Martens, 1978); (iii) buffer $\mathrm{Mg}$ concentrations of 2.5 and $5 \mathrm{mmol} / \mathrm{l}$ resemble those found in normal rumen contents but $\mathrm{Mg}$ was present almost entirely in the ionized form and thus available for absorption; (iv) buffer solution (31) was introduced into the rumen after removal of approximately 251 contents. Since the rumen significantly contracted after removal of its contents and this reduced its volume, and since rumen motility continued during the experiments, a much greater proportion of the internal rumen surface would have been in contact with the buffer solution than would be expected from the reduction of volume contents from 25 to $3 \mathrm{l}$. However, it is not certain whether in a normal rumen the internal surface in contact with coarse, non-fluid material can really be considered as an absorptive area.

Net absorption of $\mathrm{Mg}$ from the small and large intestines of ruminants is very small under normal feeding conditions. It appears likely that the low apparent digestibility of $\mathrm{Mg}$ in ruminants $(0 \cdot 10-0 \cdot 30$, Kemp et al. 1961; Rook \& Campling, 1962) is due to factors which affect the absorption of $\mathrm{Mg}$ from the forestomachs. One reason for the low apparent digestibility might be the saturation of $\mathrm{Mg}$ absorption in the rumen, which occurred above $12.5 \mathrm{mmol} / \mathrm{l}$. However, $\mathrm{Mg}$ concentration in normal rumen fluid is between 2 and $6 \mathrm{mmol} / 1$. Probably concentrations of $12.5 \mathrm{mmol} / \mathrm{l}$ and above do not occur under normal feeding conditions. Therefore it seems unlikely that the low apparent digestibility of $\mathrm{Mg}$ can be explained by a saturation of the absorptive capacity of the rumen. This conclusion is supported by the observation of Blume (1980) who found a positive and linear relationship between daily uptake of $\mathrm{Mg}$ by cows and $\mathrm{Mg}$ absorption before the duodenum. The $\mathrm{Mg}$ uptake by these cows varied between 8 and $34 \mathrm{~g} / \mathrm{d}$ and was thus within the normal range of dietary supply in both non-lactating and lactating cows. The main reason for the low apparent digestibility of $\mathrm{Mg}$ might be its low solubility in the rumen (Storry, 1961; Grace et al. 1977) and the low $\mathrm{Na}: \mathrm{K}$ value in the rumen fluid (Heggemann, 1980).

The technique applied in these studies may be subject to criticism from several points of view. (a) The accuracy of fluid volume measurements; fluid volumes are only correct if there is no absorption of the marker used. Although Dobson et al. (1976) have observed absorption of Cr-EDTA from the cow rumen, in the present experiments there was no significant disappearance of $\mathrm{Cr}$ during the experimental period. In eight experiments the mean $( \pm S E)$ amount of $\mathrm{Cr}$ contained in the buffer solution removed from the rumen after 
the experiment and in $11 \mathrm{Cr}$-free-washing buffer was $98.2 \pm 3.8 \%$. (b) Influx of endogenous $\mathrm{Mg}$ into the rumen with saliva; during the experimental periods saliva was collected by use of the saliva collector. It was shown from many previous experiments that the model used here closes the oesophagus without any leakages. (c) Efflux of a test solution containing $\mathrm{Mg}$ into the omasum; the rumen contents of the heifers used were approximately $25 \mathrm{~kg}$. Only 31 buffer solution were infused into the rumen occupying approximately $60 \%$ of the ventral sac volume. Due to the continuing forestomach motility approximately $100-150 \mathrm{ml}$ solution passed from the ventral rumen sac into the reticulum during each experimental period. Since the reticulo-omasal orifice was closed with a smooth rubber plug no fluid was lost in this direction. This was also shown by the fact that recovery of the volume marker was $98 \%$.

Caution is needed in applying conclusions from quantitative information on $\mathrm{Mg}$ efflux from an isolated and buffer-filled rumen to conditions prevailing in a normal and undisturbed rumen. It is noteworthy, however, that $\mathbf{M g}$ transport saturation in the sheep rumen wall was found irrespective of whether $\mathrm{Mg}$ was infused into a normal rumen (Field \& Munro, 1977), into a rumen pouch (Brown et al. 1978) or into a transiently isolated and washed rumen (Martens, 1979).

The author is grateful to Professor H. Höler for assistance in preparing the manuscript and to Mrs P. Loichen for technical help. This work is supported by a grant from the Government of Niedersachsen.

\section{REFERENCES}

Binnerts, W. T., van't Klooster, A. Th. \& Frens, A. M. (1968). Vet. Res. 82, 470.

Blume, R. (1980). Prae- und postduodenale Verdaulichkeit von Magnesium und Calcium bei laktierenden Kühen. Dissertation, Hannover, Tierärztliche Hochschule.

Brown, R. C., Care, A, P. \& Pickard, D. W. (1978). J. Physiol., Lond. 276, 62 P.

Dobson, A., Sellers, A. F. \& Gatewood, V. H. (1976). Am. J. Physiol. 231, 1595.

Edrise, B. M. \& Smith, R. H. (1979). Ann. Rech. Vet. 10, 354.

Field, A. C. \& Munro, C. S. (1977). J. agric. Sci., Camb. 89, 365.

Grace, N. D., Davis, E. \& Monro, J. (1977). N.Z. Jl agric. Res. $20,441$.

Heggemann, G. (1980). In vivo Untersuchungen über den Einfluss des Natrium/Kalium-Verhältnisses auf die Magnesiumabsorption aus dem Pansen von 5 bis 10 Monate alten Jungrindern. Dissertation, Hannover, Tierärztliche Hochschule.

Horn, J. P. \& Smith, R. H. (1978). Br. J. Nutr. 40, 473.

Kemp, A. Deijs, W. B., Hemkes, D. J. \& van Es, A. J. H. (1961). Neth. J. agric. Sci. 9, 134.

Martens, H. (1978). In vitro und in vivo Untersuchungen über den Magnesiumtransport durch die Pansenschleimhaut von Sc'ıafen und dessen Beeinflussung durch Futterinhaltsstoffe und Fermentationsprodukte des Pansens. Ein Beitrag zur Pathogenese der Hypomagnesämie der Wiederkäuer. Habilitationsschrift, Hannover, Tierärztliche Hochschule.

Martens, H. (1979). Berl. Münch. Tierärztl. Wschr. 92, 152.

Martens, H., Harmeyer, J. \& Michael H. (1978). Res. vet. Sci. 24, 161.

Pfeffer, E., Thompson, A. \& Armstrong, D. G. (1970). Br. J. Nutr. 24, 197.

Rogers, P. A. M. \& van't Klooster, A. Th. (1969). Meded. Landbouwhogesch., Wagen. 69, 26.

Rook, J. A. F. \& Campling, R. C. (1962). J. agric. Sci., Camb. 59, 225.

Storry, J. E. (1961). J. agric. Sci., Camb. 57, 97.

Thorlacius, S. O. (1972). Am. J. vet. Res. 33, 427.

Tomas, F. M. \& Potter, B. J. (1976). Br. J. Nutr. 36, 37.

Von Engelhardt, W. \& Sallmann, H. P. (1970). Zbl. Vet. Med. A 19, 117. 